\title{
関節トルクを用いたヒト四肢の最大カ出力分布計測法の提案 \\ Measurement of output force distribution using joint torque
}

\author{
○中西 英介，大島 徹 \\ 富山県立大学工学部知能デザインエ学科（大学院工学研究科知能デザインエ学専攻） \\ OEisuke NAKANISHI, Toru OSHIMA \\ Dept. of Intelligent System Design Eng. , Toyama Prefectural Univ.
}

\section{1. はじめに}

四肢の関節トルクの計測手法とそれによる計測結果が独立行 政法人製品評価技術基盤機構／生活·福祉技術センタ一から人

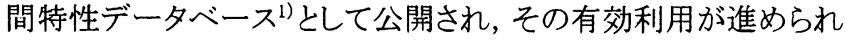
ている.しかし，二関節筋の存在によって関節が独立ではないこ とが明らかであるにもかかわらず，四肢の関節トルクの計測手法 で計測される関節トルクは, それぞれの関節が独立であることが 前提であるため, ここに差異が生じる. そのため, 人間特性デー タベースの関節トルクを安易に用いてヒト四肢の最大力出力分布 を論じることの誤りが過去の研究により明らかにされている. ${ }^{2)}$ 関 節卜ルクによる最大力出力分布は二関節筋の存在を考慮しない ため, 二関節筋を有するヒト四肢の最大出力分布とは異なる. 本 研究は人間特性データベースの関節トルクを用いて, 一関節筋 の影響を考慮した四肢の最大出力分布を得る手法を提案する.

\section{2. 実験による比較検証}

機能別実効筋力による出力分布の計測に示されている手順 ${ }^{2)}$ により, 手根関節 $\mathrm{J}_{3}$ における力出力の大きさとその方向を計測し, 力出力分布を求めた. 同時に, 関節トルクの計測手法に示されて いる手順”により, 肩関節 $\mathrm{J}_{1}$ における肩関節トルクと时関節 $\mathrm{J}_{2}$ にお ける肘関節トルクを個々に計測し，これにより出力分布を求めた. ここで, 肩関節 $\mathrm{J}_{1}$ の関節角度 $\theta_{1}$, 时関節 $\mathrm{J}_{2}$ の関節角度 $\theta_{2}$ は中立 位とした。

図 1 に, ある被験者の計測結果を示す. 白丸は手根関節 $\mathrm{J}_{3}$ で 直接計測された力出力, 実線の六角形 $\mathrm{ABCDEF}$ はこれらより求め た力出力分布を示す. 点線の四角形 $\mathrm{PQRS}$ は, 関節トルクの計測 手法により計測された関節トルクより求めた出力分布である. 対象 がヒトであることから牛.じるばらつき ${ }^{3)}$ 考慮すると, 他の被験者の 結果からもそれぞれの計測手法の再現性, 異なる計測手法間の 整合性は十分であると考えられる. 関節トルクより求められた四角 形の出力分布は明らかに誤りである.

\section{3. 出力分布の汁測法の提案}

図 1 に示す計測結果にあるように，手根関節 $\mathrm{J}_{3}$ で数十点の 力出力を計測することは, 被験者への負担を考えると現実的 ではない，ここでは，新たに関節トルクを利用した手法を提 案する. 図 2 に示すように, カセンサを手根関節 $\mathrm{J}_{3}$ に固定し た状態で関節トルクを計測する. 図 2 に示すように, 时関節 $\mathrm{J}_{2}$ をコルセットで固定することで，手根関節 $\mathrm{J}_{3}$ で肩関節トル ク $T_{\mathrm{f} 1+\mathrm{f} 3}, T_{\mathrm{e} 1+\mathrm{e} 3}$, を計測することが可能である。.また, 上腕 を保持することで肘関節トルク $T_{\mathrm{f} 2+\mathrm{f} 3}, T_{\mathrm{e} 2+\mathrm{e} 3}$ を同様に計測す ることが可能である.このようにして関節トルクを計測し， さらにPの方向の力出力を計測することで, 六角形の力出力分 布ABCDEFを得ることができる.これは，カセンサの付け替え などを必要とせず，容易に計測できる．図 3 には，このよう にして求めた六角形の力出力分布を点線で示す。このような 方法で，十分に力出力分布を再現できると考えられる．実際 には, 肩関節トルクのほうが肘関節トルクより大きいために, 肘関節トルクの計測には上腕を保持する必要はない.

\section{4. おわりに}

四肢の関節トルクの計測手法とそれによる計測結果が独立行 政法人製品評価技術基盤機構／生活・福祉技術センタ一からデ 一タベースとして公開1)され，これらを利用する分野の大きな進展 が期待される.ここでは, 関節トルクの計測手法を否定するもので
はない.この手法により計測された関節トルクは, 関節それぞれに 着目した場合の関節トルクであり, 二関節筋による関節間の相互 作用は考慮されていないために,これまでの多関節系の力学を 適用して, ここから出力を求めることは誤りであることを明確にした 上で出力を論じる, あるいは製品設計などを行う必要があることを 強く示唆するものである. さらに, 関節卜ルクの計測手法をべース とした力出力分布の計測手法の新たな提案は関節トルクと筋力を 明確に区別する一助ともなる.

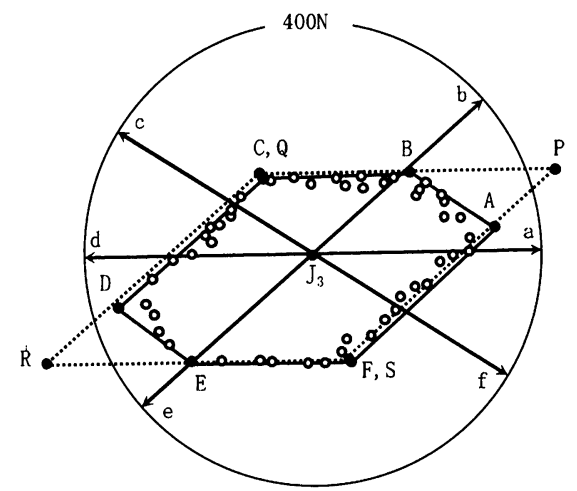

Fig. 1 Measured output force distribution

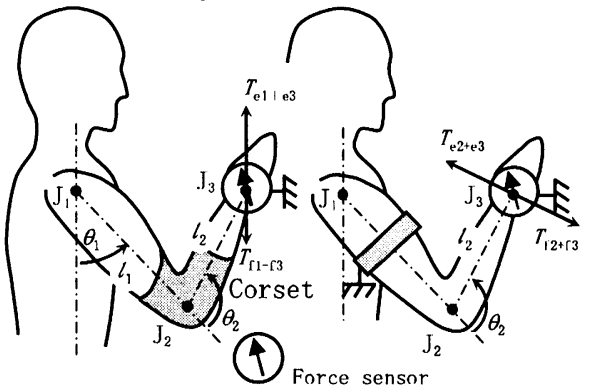

Fig. 2 New method for joint torque

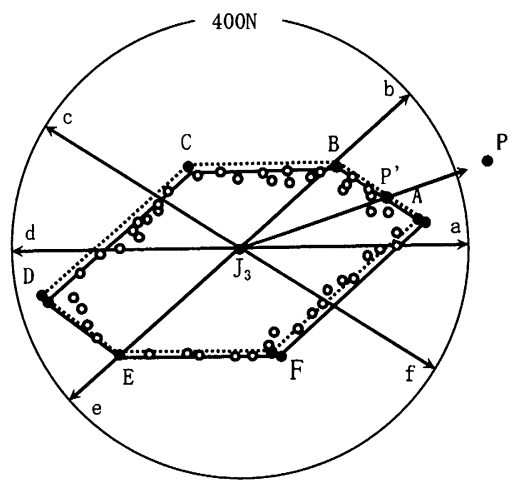

Fig. 3 Output force distribution measured by new method 务文献

1）人間特性データベース(http://www.tech.nite.go.jp/human/)

2）大島 徹, 藤川智彦, 熊本水頼:一関節筋および二関節筋を 含む筋座標系による機能別実効筋力評価（筋力と四肢先端 の出力), 精密工学会誌, 1999, 65, (12) 1772.

3）大島 徹, 藤川智彦, 熊本水頼:一関節筋および二関節筋を 含む筋座標系による機能別実効筋力評価(出力分布の簡な 計測法), 精密工学会誌, 2001, 67, (6) 943. 